Applied Physiology, Nutrition, and Metabolism

Canadian

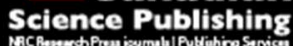
Physiologie appliquée, nutrition et métabolisme

\title{
Exploring the utility of cardiorespiratory fitness as a population health surveillance indicator for children and youth: An international analysis of results from the $\mathbf{2 0 ~} \mathrm{m}$ shuttle run test
}

\begin{tabular}{|r|l|}
\hline Journal: & Applied Physiology, Nutrition, and Metabolism \\
\hline Manuscript ID & apnm-2017-0728 \\
\hline Manuscript Type: & PhD Thesis Abstract \\
\hline Date Submitted by the Author: & 27-Oct-2017 \\
\hline $\begin{array}{r}\text { Complete List of Authors: } \\
\text { Is the invited manuscript for } \\
\text { consideration in a Special } \\
\text { Issue? : }\end{array}$ & \\
\hline Keyword: & $\begin{array}{l}\text { performance }<\text { performance, pediatrics < pediatrics, aerobic evaluation }< \\
\text { aerobic evaluation }\end{array}$ \\
\hline \multicolumn{2}{|c}{} \\
\hline
\end{tabular}


Title: Exploring the utility of cardiorespiratory fitness as a population health surveillance indicator for children and youth: An international analysis of results from the $20 \mathrm{~m}$ shuttle run test

Date of acceptance: September $7^{\text {th }}, 2017$

Date of convocation: November $5^{\text {th }}, 2017$

Author: Justin J. Lang

Author's current affiliation: Public Health Agency of Canada, Centre for Surveillance and Applied Research, Applied Research Division

Author's affiliation during PhD studies: Healthy Active Living and Obesity Research Group, Children's Hospital of Eastern Ontario Research Institute

Advisor: Mark Tremblay

Advisor's department: Healthy Active Living and Obesity Research Group, Children's Hospital of Eastern Ontario Research Institute

\footnotetext{
ABSTRACT

Emerging evidence has demonstrated the strong link between cardiorespiratory fitness and multiple aspects of health (i.e., physiological, physical, psychosocial, cognitive), independent of physical activity, among school-aged children and youth. Cardiorespiratory fitness is a trait that does not vary substantially from day-to-day, and provides an indication of recent physical activity levels, making it an important possible indicator of population health. Thus, the objective of this dissertation was to investigate the utility of cardiorespiratory fitness, measured using the $20 \mathrm{~m}$ shuttle run test, as a broad, holistic health indicator for population health surveillance among children and youth. To achieve this objective we completed seven manuscripts, all prepared for submission to peer-reviewed, scientific journals:
} 
1. Systematic review of the relationship between $20 \mathrm{~m}$ shuttle run performance and health indicators among children and youth.

2. Review of criterion-referenced standards for cardiorespiratory fitness: What percentage of 1142026 international children and youth are apparently healthy?

3. Cardiorespiratory fitness is associated with physical literacy among Canadian children aged 8 to 12 years.

4. International variability in $20 \mathrm{~m}$ shuttle run performance in children and youth: Who are the fittest from a 50-country comparion? A systematic review with pooling of aggregate results.

5. Making a case for cardiorespiratory fitness surveillance among children and youth.

6. International normative $20 \mathrm{~m}$ shuttle run values from 1142026 children and youth representing 50 countries.

7. Temporal trends in the cardiorespiratory fitness of 965264 children and youth representing 19 countries since 1981.

Combined, this dissertation provides support for the importance of cardiorespiratory fitness for health surveillance among school-aged children and youth. Results from the international analysis highlighted the variability across countries, with countries in North-Central Europe and Africa having the highest cardiorespiratory fitness, and countries in South America having the lowest cardiorespiratory fitness. The results indicated that declines in cardiorespirtory fitness may have stabilized in recent years in some high- and middle-income countries. This dissertation also identified two methods (criterion- and normative-referenced standards) to interpret 
cardiorespirtory fitness levels among children and youth, methods that could be used to inform future consensus, surveillance, and cardiorespiratory fitness guidelines.

Current assignment/research: I am currently working as a Research Analyst with the Public Health Agency of Canada. In this role my responsibilities include: oversee and support ongoing research projects aimed at improving the health of Canadians; contribute to knowledge translation to help inform Canadians about our work; support research ethics board applications; co-advise students; inform and assist other Agency departments. Currently, I am also leading three unique research projects: (1) development of criterion- and normative-referenced standards for cardiorespiratory fitness in Canadian adults; (2) leading a Canadian Global Burden of Disease project; and (3) contributing to the psychometric evaluation and development of normative centile values for the Strengths and Difficulties Questionnaire to screen for mental health issues in Canadian children and youth. 